\title{
MÜHELY
}

\section{A finn exonima-adatbázis}

1. Az exonima/endonima fogalompár. Az exonima/endonima fogalompár jelentéstartalmáról mind a mai napig nem szüntek meg a viták. Nincs ezen mit csodálkozni, hiszen olyan fogalmakról van szó, amelyeknek a tárgyai, azaz a földrajzi nevek alapvetően egy-egy nyelv, nyelvi környezet és kultúra szférájába tartoznak; magukat a fogalmakat ugyanakkor külső, az egyértelmü nemzetközi kommunikáció biztosítását szolgáló, gyakorlati jellegü igények (a földrajzi helyek különböző nyelvü megnevezéseinek egymással való megfeleltetése, szelektálás, nemzetközi használatra szánt változatok kiemelése) tették szakmai körökben szükségessé. Az ENSZ Földrajzinév-szakértői Csoportja (UNGEGN) az évtizedek során több definíciót is kidolgozott a fogalmakra. Az első, 1972-ből származó meghatározás még aszerint minősítette endonimának vagy exonimának a földrajzi neveket, hogy azok az adott helyen hivatalos nyelvü alakok-e vagy sem (történeti áttekintésére 1. Poкоцy 2013). A hivatalos nyelvhez kötés számos, különösen a kisebbségek identitásához köthető problémát vetett fel. Az UNGEGN ma is használt meghatározása a „széles körben használt nyelv" formulájának bevonásával lényegesen megengedőbb, mint a korábbi definíció (vö. BöLCSKEI-FARKAS-SLíz 2017: 136-137), az utóbbi időben a szakértők mégis több kísérletet tettek egy új meghatározás megszövegezésére (pl. JoRDAN 2012: 2, NySTRÖM 2014: 36, Woodman 2014: 13). Ezek alapvetően nem a nyelvre, hanem a helyi közösség névhasználatára helyezték a hangsúlyt, jelezve, hogy bármilyen merev, a jogiközigazgatási helyzetre építő, gyakorlati célzatú meghatározás óhatatlanul az emberi közösségek, az emberi kultúra földrajzi nevekben megörzött örökségének a sérelmével járhat.

E vitáknak is köszönhető, hogy számos országban modern, rendszeresen frissített exonimaadatbázisokat hoztak létre. Ezeknek az előzményeként már az ENSZ 1972-es Földrajzinévegységesítési Kongresszusa javasolta, hogy a tagállamok létesítsenek exonimaregisztereket, és ezeket osszák meg egymás közt. Összetett és érzékeny feladatról van szó. Egyrészt természetes, hogy minden nemzeti kultúra ragaszkodik a maga meggyökeresedett földrajzi neveihez, másrészt nem szabad szem elől téveszteni a történelmi-generációs aspektusokat (vö. BÖLCSKEI-GERCSÁK-MiKESY 2018), az átírási szokások változásait, a földrajzi objektum jellegét (pl. városról vagy természetföldrajzi egységről van-e szó), de akár a vitatott szuverenitású területekkel kapcsolatos politikai megfontolásokat sem. Egy exonimaregiszter csak szelektált, a készítők nyelvi-történelmi-kulturális környezete által motivált fontossági sorrend szerint megállapított lista lehet. Bár az exonimalisták eredendően tartalmaznak szubjektív elemeket, vitathatatlanul hozzájárulnak a nemzeti kultúrához, amennyiben a térképek, szótárak, tananyagok, menetrendek, a sajtó, turisztikai prospektusok stb. egységes névhasználatát, a világ különböző helyeiről való élő kommunikációt segítik. 
2. A finn exonimák interneten elérhető adatbázisa. A finn exonimák válogatott listája 2018 óta digitálisan, jól kereshető adatbázisban érhető el a Kotimaisten kielten keskus (azaz a Hazai Nyelvek Központja, rövidítve: KOTUS) honlapján. ${ }^{1}$ A kezdetben kétezer rekordot számláló adatbázis tartalma mára háromezer rekord fölé emelkedett. A lista nyelvészek és geográfusok több évtizedes együttmüködésének az eredménye (vö. HAKULINENPAIKKALA 2019), amely a KOTUS feladatköréből adódóan normatív jellegü. A földrajzi objektumok listáját KERKKO HAKULINEN vezetésével állították össze, a végső nyelvi megformálás a KOTUS SiRKKa PAiKKala irányításával müködő nyelvészeinek az érdeme. A szelektálás erősségéhez adalék, hogy mindössze tizennégy mai magyarországi objektum elnevezése szerepel benne (pl. Gellértinvuori [Gellért-hegy], ${ }^{2}$ Iso-Kumania [Nagykunság]) a több ország területét érintő helyekkel együtt (pl. Neusiedlerjärvi [Fertö], Tonava [Duna], Pieni Unkarin alanko [Kisalföld]), s ezek között egyetlen település- vagy megyenév sincs. Portugália öt, Szerbia tíz hellyel van jelen. Egyetlen „ház” osztályba sorolt objektum van benne, a washingtoni Valkoinen talo (Fehér Ház). Ezzel szemben a Spitzbergák (Svalbard) 27 objektummal van jelen, ami mutatja, hogy a szerkesztők a finn nyelvü nevekre fókuszáltak, a nevek adott területen való sürüségére nem.

A honlapon nem található nyelvválasztó funkció, tehát az idegen anyanyelvủ használóknak is a finn nyelvủ szakszók és leírások segítségével kell eligazodniuk, és így ebben az ismertetésben is szükséges lesz néhány szónak a jelentését megadni. A választható menüsorban a Nimet ('Nevek') opciót választva jutunk el az adatbázis fő táblájához. Az Etusivu ('Kezdőlap'), Käyttöohje ('Használati utasítás'), Oikeinkirjoitus ('Helyesírás'), Taustaa ('Háttér'), Palaute ('Visszacsatolás') opciókkal különböző tájékoztató szövegekhez jutunk.

Az adatbázis kétharmad részben természetföldrajzi neveket tartalmaz. Ennek csak részben oka az összeállító geográfusi akkurátussága; lásd például a tengeri áramlatok és a tengerfenék részletes nevezéktanát: Eteläinen päiväntasajanvirta (Egyenlítői déli áramlat), Keski-Tyynenmeren allas (Közép-Csendesóceáni-medence), Tšsutšien syvänmerentasanko (Csukcs-fenéksíkság). További fontos szempont, hogy a természetföldrajzi névtípusokban a legelterjedtebbek világszerte a fordítási műveletek, amelyek legalább a földrajzi közneveket és jelzőket érintik; pl. Ontariojärvi (Ontario-tó), Skandinavian niemimaa (Skandinávfélsziget), Itä-Kaarpatit (Keleti-Kárpátok), Pohjois-Ural (Északi-Urál), de igen gyakoriak a megkülönböztető elemekben is: Pirunsaari (Ördög-sziget, ang. Devil's Island), Iso Karhujärvi (Nagy-Medve-tó, ang. Great Bear Lake).

Az is a természetföldrajzi kategória túlsúlyát eredményezi, hogy a finn tudományban közel másfélszáz éves hagyománya van annak a gyakorlatnak, hogy csak a legfontosabb városok, országok nevét írják finnesen, a finn kiejtés alapján, a finn mássalhangzókészlet viszonylagos szükössége ugyanis kezelhetetlen mennyiségü névalakot eredményezett volna. A 259 városnévi találatból csak alig néhány tucatnyi a hagyományos finn exonima; pl. Berliini (Berlin), Kaapkaupunki (Fokváros), Kiova (Kijev), Kööpenhamina (Koppenhága), Lontoo (London), Pariisi (Párizs), Pietari (Szentpétervár), Pihkova (Pszkov), Riika (Riga), Rooma (Róma), Tallinna (Tallinn), Tukholma (Stockholm), Väinänkaupunki (Daugavpils), Varsova (Varsó), Vilna (Vilniusz).

\footnotetext{
${ }^{1}$ https://kaino.kotus.fi/eksonyymit (2020. 12. 02.)

2 Írásomban kivételesen nem minden nyelvi adat dőlt betűs, csak a bemutatott adatbázisban rögzített, visszakereshető alakok.
} 
Erős csoportot képeznek - mondhatni természetesen - a bibliai és az ókori történelmi helyszínek nevei: Baalbek, Betlehem, Damaskos, Jeriko, Nasaret, Tiberias, illetve Ateena, Korintti, Sparta. Az adatbázis önmeghatározása szerint a külföldi helyek nevét tartalmazza, így a Finnország határain kívül lakó finnek tulajdonképpen endonimának számító nevei is benne vannak a gyüjteményben; pl. Aunuksenkaupunki (Olonyec), Karhumäki (Medvezsjegorszk), Käkisalmi (Priozjerszk), Petroskoi (Petrozavodszk), Pähkinalinna (Slisszelburg), Viipuri (Viborg), illetve Haaparanta (Haparanda), Jällivaara (Gällivare), Uumaja (Umeå). A városnévi exonimák többségét a helyi hivatalos nyelvi alakkal szemben a finnek által is preferált, nemzetközileg elterjedt alakok adják: Aden, Bangkok, Doha, Gaza, Haifa, Hanoi, Istanbul, Kabul, Mosul, Port Said, Pristina, Rabat, Tripoli stb. A listán nem található olyan exonima, amelyet nem latin betüs írású nyelvböl közvetlenül vettek volna át, akár finn ejtés szerinti írással, akár szabványos transzliterációval. Az angolon kívül szép számmal találunk a finnben német közvetítéssel meghonosodott névalakokat is: Assuan (ang. Aswan), Belgrad (ang. Belgrade), Bukarest (ang. Bucharest), Havanna (ang. Havana), Kairo (ang. Cairo), Lissabon (ang. Lisbon), Mekka (ang. Mecca), Nikosia (ang. Nicosia), Peking (ang. Beijing), Teheran (ang. Tehran), Tokio (ang. Tokyo). Számos változatlan helyi névforma, azaz endonima is található a finn exonimák oszlopában. Ezt a megoldást akkor alkalmazták, ha több hivatalos nyelvü alak is létezik a város jelölésére, de finn használatra ezek közül egyet javasolnak: pl. Almaty, Baikonur, Bern, Dublin, Luxemburg, N’Djamena, New Delhi.

A régiók félezernél nagyobb darabszámú kategóriája meglehetősen heterogén. Találhatók itt kontinensrészek, országcsoportok - pl. Itä-Afrikka (Kelet-Afrika), Atlasmaat (Atlaszországok), Latinalainen Amerikka (Latin-Amerika), Lähi-itä (Közel-Kelet) - ugyanúgy, mint jelenlegi és történelmi tartományok, országrészek, szövetségi államok, közigazgatási területek, tájak, ha írott alakjuk különbözik a helyben használt alaktól - pl. Baijeri (Bajorország), Bessarabia, Havai, Hertsegovina, Kalifornia, Kastilia, Hantien ja mansien autonominen piirikunta (Hanti-Manysi Autonóm Körzet) -, de iparvidékek, turisztikai régiók és egyéb övezetek, kisebb egységek is; pl. Piilaakso (Szilícium-völgy), Ruhrin alue (Ruhr-vidék), Aurinkorannikko (Costa del Sol).

Az országok listája sem teljes, hasonlóképpen a városokhoz, csak a finnben saját névvel bíró (pl. Norsunluurannikko [Elefántcsontpart], Viro [Észtország]) vagy eltérô írásképet mutató (pl. Meksiko [sp. México], Romania [rom. România]) országok vannak benne a függő területekkel (pl. Brittiläiset Neitsytsaaret [Brit Virgin-szigetek]) együtt. Bolívia (Bolivia) és Namíbia (Namibia) neve például nincs az adatbázisban, mivel ezek írásképe a helyi hivatalos nyelven és a finnben megegyezik. Nem latin betüs írású országnevek esetében a nemzetközi alakokat használják a finnek (Libya, Mongolia, Montenegro), vagy azok szolgálnak a finn megnevezés alapjául (Jordania, Kambodža). Ebben a kategóriában, ahol az egyedi ajánlás szükséges és elvárható lenne, meglehetősen szokatlan a kettős-hármas megoldások nagy száma; pl. Bosnia ja Hertsegivina $\sim$ Bosnia-Hertsegovina, Britannia Iso-Britannia $\sim$ Yhdistynyt kuningaskunta [Egyesült Királyság], Hollanti $\sim$ Alankomaat [Hollandia], Kookossaaret [Kókusz-szigetek] Keelinginsaaret, Myanmar $\sim$ Burma.

Kevésbé terhelt kategóriák az építmények és mesterséges szerkezetek nevei (31 helyszín vagy objektum, pl. Assuanin suurpato [Asszuáni gát], Kaarlensilta [Károly-híd], Eiffel-torni [Eiffel-torony], közlekedési utak nevei (54, pl. Baikalin-Amurin rata [BajkálAmur vasút], Reinin-Mainin-Tonavan kanava [Duna-Rajna-Majna-csatorna]) és ősi örökségek (37, pl. Heliopolis, Hadrianuksen valli [Hadrianus fala]). Ez a minimális szám 
nyilvánvalóan csak egy mutatványt takar, és ebben az esetben nem érvényes, hogy amelyek nincsenek itt, azoknak a hivatalos nyelvi alakja az irányadó.

Az adatbázisban - az ENSZ ajánlásának megfelelöen - következetesen exonimának tekintik a mindössze diakritikus jegyekben eltérő alakokat is; pl. Panama Panamá, Sanaa $\sim$ San'a. Erősen korlátozták az olyan nevek szerepeltetését, amelyekben egy külföldi hely finn nevében mindössze a földrajzi köznév fordítása teremt exonimát, de a megkülönböztető elem érintetlenül marad; például nincs benne a listában Mansaari Isle of Man (Man sziget). Az állami szuverenitás alá nem tartozó helyek esetében (alapvetően a világtenger és a tengerfenék részei) az angol alakot tekintették kiindulási alapnak, kvázi-endonimának. Az adatbázisban a finn exonimák valamennyi hivatalos nyelvü alakja megtalálható, nem latin betűs írás esetén standard romanizált átírásban. Az angol nyelvü változatok minden esetben megtalálhatók, ha vannak (majdnem mindig vannak), továbbá egyéb nyelvi (többnyire német és francia) alakokat, esetleg a szomszédos nyelvekből származó adatokat is megkapunk.

3. Az adatbázis szerkezete. A főtáblában hat oszlop található. A finn exonimák állnak az első oszlopban; ezekhez a következő adatok járulnak: a hely földrajzi jellege (tenger, öböl, város stb.), a befogadó nagyobb egység (ország, kontinens, óceán stb.), a hely angol neve, a hely neve a honos nyelveken, továbbá számos névadat egyéb (jellemzően francia és német, illetve szomszédos) nyelveken. Az első oszlop nevei egyben linkek, rájuk kattintva szövegesen találjuk meg a táblázatban foglalt információkat, esetenként még többet is; például Thaiföld (Thaimaa) esetében tájékozódhatunk a Sziám (Siam) változat időbeli érvényességéről. Valamennyi oszlop ábécébe rendezhetö.

A főcím és a menüsor között találjuk a keresőmezőt, amelyben névre és névrészekre lehet keresni (Hae nimellä, azaz 'Keress a névre'). Ez alatt találjuk az összetett keresésekre szolgáló Tarkennettu haku ('Célzott keresés') opciót. A kinyíló ürlap öt mezőjének segítségével lehetőség van arra, hogy egy bizonyos nyelv névadatait kapjuk meg. A nyelvek imponáló bőségéből (valamennyi helyben hivatalos nyelv adatai szabványos romanizált átírással) legördülő menüből választhatunk. A földrajzi jellegek 148 megállapított kategóriáját 11 nagyobb osztályba szervezték, így a tengereket, tengeri öblöket, óceánokat, áramlatokat stb. a tengeri területek egységébe. A földrajzi jellegek és osztályaik ugyancsak legördülő menüből választhatók ki. A nagyobb, befoglaló földrajzi egységekre (országok, kontinensek stb.) viszont beírással kereshetünk rá.

1. táblázat: Az összetett keresés menüje

\begin{tabular}{|l|l|}
\hline \multicolumn{1}{|c|}{ Finn kifejezések } & \multicolumn{1}{c|}{ Magyar megfelelök } \\
\hline nimellä tai nimenosalla & névre vagy névrészre \\
\hline nimen kielellä & a név nyelvére \\
\hline paikan lajityypillä & a hely jellegének osztályára \\
\hline paikan lajilla & a hely jellegére \\
\hline paikan sijainnilla & a hely tágabb környezetére \\
\hline
\end{tabular}

Az öt lehetőség tetszés szerint kombinálható. Az albán nyelvre való keresésre 23 találatot kapunk; ha hozzávesszük Albániát mint befoglaló helyet, akkor 15 Albánián belül 
található helyet kapunk finn névvel. Ha a kontinentális vízneveket is bekapcsoljuk, akkor négy tóra és három folyóra szükül a találatok száma. De például azt is megtudhatjuk a különféle keresésekböl, hogy a közép-európai városnevek adataihoz nem vontak be magyar nyelvü forrást, míg távolabbi nyelvek adatai előfordulnak.

2. táblázat: A földrajzi jellegek osztályai

\begin{tabular}{|l|l|}
\hline \multicolumn{1}{|c|}{ Finn kifejezések } & \multicolumn{1}{c|}{ Magyar megfelelök } \\
\hline alueet & területek (kis és nagy régiók) \\
\hline liikennereitit & közlekedési útvonalak \\
\hline maankamaran ja kasvillisuuden muodot & természetes felszíni és vegetációs alakulatok \\
\hline maat & országok \\
\hline mannerten vedet & kontinentális vizek \\
\hline mantereet ja maanosat & kontinensek és részeik \\
\hline merenpohjan muodot & tengerfelszín alatti alakulatok \\
\hline merialueet & tengerek, tengerrészek \\
\hline muinaisjäännökset & ösi örökségek \\
\hline paikkakunnat ja niiden osat & lakott helyek és részeik \\
\hline rakennelmat & építmények, mesterséges létesítmények \\
\hline
\end{tabular}

A kombinált keresések nemcsak a finneket segíthetik, hiszen a nyelvek, a helyek és földrajzi jellegek kombinációjával a különböző nyelvü nevek gazdag tárháza nyílik meg. Például a Balkán-félsziget nevét mind a nyolc helyi és még négy további nyelven megkapjuk, Európa nevét hat nem európai nép nyelvén stb.; a lehetőségek sorolása külön tanulmányt érdemelne.

4. Magyarország és a magyar nevek reprezentációja. Magyar szemszögböl tekintve az adatbázist, többféle tapasztalatunk lehet. A Kárpát-medence nagy egységei közül néhánynak megtaláljuk a magyar nevét, pl. Bánát, Bihar-hegység, Erdély, Erdélyi-medence, Szerémség, de vannak, amelyek bántóan hiányzanak a magyarok által is lakott régiókból: pl. Karpaatit (Kárpátok), Korkea-Tatra (Magas-Tátra), Matala-Tatra (Alacsony-Tátra), Slavonia (Szlavónia). A Kis-Kárpátok esetében a német alakot is endonimának tüntetik fel, magyar névadat pedig nincs. Kárpátalja (Transkarpatia) esetében észt, francia, német adatok is vannak, a legjelentősebb helyi kisebbség nyelvén azonban nincs névadat. E mögött nemigen tételezhető fel rossz szándék, inkább a források körültekintőbb megválasztását hiányolhatjuk. Az utóbbi régió egyébként Karpaatti-Ukraina Karpaatti Rutenia néven külön is benne van az adatbázisban, ami mutatja, hogy a források összefésülése nem mindenütt volt egyenletes. Az Iso Unkarin alanko (Alföld) alak mögött az angol Great Hungarian Plain húzódik meg, a tájegység Szlovákiára és Horvátországra való kiterjesztését pedig arra vezethetjük vissza, hogy a hosszú angol névalakot igen kis méretarányú térképről vehették (több hasonló eset is van, például a Beszkidek áthúzódása Romániára, a Keleti-Kárpátok adatolása Szlovákiában). Furcsállhatjuk a Kunság bő adatolását (Kumania [Kunság], Iso-Kumania [Nagykunság], Pieni-Kumania [Kiskunság]) olyan viszonyok között, ahol nem jutott hely a Kékesnek, a Tisza-tónak, a Hortobágynak, a Marosnak, a Rábának vagy a Szamosnak. Az utóbbi három folyó országhatárokon is átfolyik, így esetükben nem lehet „a” hivatalos alakot ajánlani. Ezeknél kisebb vízfolyások ugyanakkor bőséggel vannak az adatbázisban. 
5. Összegzés. Megállapíthatjuk, hogy a finn exonimák interneten elérhető gyüjteménye esetében egy rendkívül gazdag, felhasználóbarát módon kialakított adatbázisról van szó, amely jól szolgálhatja a finnek, finnül tudók tájékozódását a világban, támogatja a sajtó, a tananyagok, a turisztika stb. névhasználatát, hozzájárulhat a földrajzi szaknyelv egységesítéséhez. Az összeállítás nemzetközi ajánlásnak tesz eleget, egyszersmind mintául szolgálhat más országok szakemberei számára is. Semmilyen hasonló nagyságú névállományt nem tekinthetünk tökéletesnek, befejezettnek, így a finn adatbázisba is újabb és újabb forrásokat vonnak be. Minőségi ugrás pedig akkor várható, ha más országok, illetve hivatalos státussal nem bíró nyelvek felelős intézményei is elkészítik a maguk exonima-adatbázisait, és azokat megosztják a nemzetközi közösséggel.

\section{Hivatkozott irodalom}

Bölcskei Andrea - Gercsák Gábor - Mikesy Gábor 2018. Hol van Abbázia? Egy kérdőíves felmérés tanulságai. Névtani Értesitö 40: 103-117. https://doi.org/10.29178/nevtert.2018.6

Hakulinen, KerkKo - Paikkala, SirkKa 2019. The Finnish exonym gazetteer on the internet. History, selection of names, content. In: Dollimore, Allison - Jordan, Peter eds., The Classification of Exonyms. Proceedings of the 21th UNGEGN Working Group on Exonyms Meeting, Riga, 24-26 September 2018. Verlag Dr. Kovač, Hamburg. 151-162.

Jordan, Peter 2012. Towards a comprehensive view at the endonym/exonym divide. Submitted by Austria. 10th UNCSGN Conference, New York. E/CONF.101/73. http://unstats.un.org/ unsd/geoinfo/UNGEGN/docs/10th-uncsgn-docs/econf/E_CONF.101_73_Towards\%20a\%20 comprehensive\%20view.pdf

Bölcskei Andrea - Farkas Tamás - Slíz Mariann szerk. 2017. Magyar és nemzetközi névtani terminológia / Hungarian and International Onomastic Terminology. International Council of Onomastic Sciences - Magyar Nyelvtudományi Társaság, Uppsala-Budapest. https://doi. org/10.26546/5061110

Nyström, StafFan 2014. Endonym and exonym - basically linguistic concepts after all? In: Jordan, Peter - Woodman, Paul eds., The Quest for Definitions. Proceedings of the 14th UNGEGN Working Group on Exonyms Meeting, Corfu, 23-25 May 2013. Verlag Dr. Kovač, Hamburg. $33-38$.

PoKoly Béla 2013. Az exonima kifejezés értelmezésének változása a földrajzinév-egységesítés nemzetközi gyakorlatában. Névtani Értesitö 35: 71-75.

Woodman, Paul 2014. The scope of activities of the UNGEGN Working Group on Exonyms, and the definitions of endonym and exonym. In: Woodman, Paul ed., The Quest for Definitions. Proceedings of the 14th UNGEGN Working Group on Exonyms Meeting, Corfu, 23-25 May 2013. Verlag Dr. Kovač, Hamburg. 9-20.

MiKesy GÁBor

ORCID: https://orcid.org/0000-0003-0232-1396

Lechner Tudásközpont Nonprofit Kft.

Ingatlan-nyilvántartási és Geodéziai Igazgatóság 


\section{GÁbor Mikesy, The Finnish database of exonyms}

In Finland, a detailed, regularly updated and complex searchable database of exonyms has been available on the website of the Institute for the Languages of Finland since 2018. The database, compiled through the collaboration of geographers and linguists, currently has about three and a half thousand entries and contains a fair number of Finnish geographical names for locations outside of Finland, or names of Finnish origin used outside of Finland. The latter should be noted because the dictionary also includes the names from areas of neighbouring countries where Finnish is spoken. The database contains a wealth of information regarding the different names for geographical objects (even beyond names used in the official language of a given place). Thus it presents itself as an outstanding source of data for those who do not speak Finnish. The Finnish exonym database is also an excellent model for researchers in other countries to follow. 